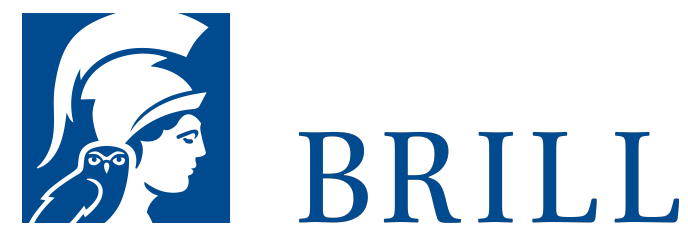

\title{
A Man Comes from Someplace
}

Stories, History, Memory from a Lost Time

Author: Judith Pearl Summerfield

A Man Comes from Someplace: Stories, History, Memory from a Lost Time is a cultural study of a multi-generational Jewish family from a shtetl in southwestern Ukraine before World War I to their international lives in the 21st century. The narrative, told from multiple perspectives, becomes a transformative space for re-presenting family stories as cultural performance. The study draws from many sources: ethnographic interviews with an oral storyteller (the author's father), family letters, papers from immigration and relief organizations of the 1920s, eyewitness reports, newspaper clippings, photographs, maps, genealogy, and cultural, historical, and literary research.

The book investigates the ways family stories can be collected, interpreted, and re-presented to situate story in history and to re-envision connections between the past, present, and future. Family stories become memory sites for interrogating questions of loss and displacement, exile, immigration, survival, resilience, and identity. Stories function as antidotes to trauma, a means of making sense of the world. Memory is an act of resistance, the refusal to be silenced or erased, the insistence that we know the past and remember those who came before.

Readership

Educational Researchers and their students

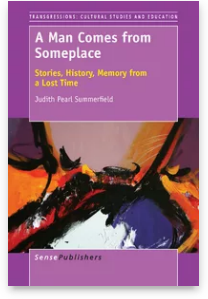

Pages: 250 pp.

Language:

English

Subjects:

General,

Education,

Culture \&

Education,

Education

Publisher: Brill

Series:

Transgressions:

Cultural Studies and Education,

Volume: 110

Hardback

Publication date:

O1 Jan 2015

ISBN: 978-94-

6300-189-2

Paperback

Publication date:

o1 Jan 2015

ISBN: 978-94-

6300-188-5 
Judith Pearl Summerfield, Professor Emerita in English, Queens College, The City University of New York, is the recipient of numerous awards and grants for teaching, scholarship, and research. She has written extensively about rhetoric, composition, narrative studies, and education. In 2011, she found her way back to the place her family had come from in Ukraine.

For more information see brill.com

Order information: Order online at brill.com +44330 333 o049 | customerservices@brill.com Submission information: brill.com/authors

Titles published by Brill | Fink, Brill | mentis or Brill | Schöningh: +49(o)71 5413279216 | brill@brocom.de 